Article

\title{
Electrochemical Mineralization of Ibuprofen on BDD Electrodes in an Electrochemical Flow Reactor: Numerical Optimization Approach
}

\author{
Alejandro Regalado-Méndez ${ }^{1,2} *{ }^{\mathbb{C}}$, Martín Ruiz ${ }^{1}$, José A. Hernández-Servín ${ }^{3}{ }^{(D}$, \\ Reyna Natividad $^{2}\left(\mathbb{D}\right.$, Rubi Romero ${ }^{2}$, Mario E. Cordero ${ }^{4}{ }^{D}$, Carlos Estrada-Vázquez $^{1}$ and \\ Ever Peralta-Reyes 1,2,*(D) \\ 1 Campus Puerto Ángel, Universidad del Mar, Puerto Ángel 70902, Mexico; mrm3092@hotmail.com (M.R.); \\ cestrada@angel.umar.mx (C.E.-V.) \\ 2 Centro Conjunto de Investigación en Química Sustentable, UAEMex-UNAM, Universidad Autónoma del \\ Estado de México, Toluca 50200, Mexico; reynanr@gmail.com (R.N.); rromeror@uaemex.mx (R.R.) \\ 3 División de Computación, Facultad de Ingeniería, Universidad Autónoma del Estado de México, \\ Toluca 50100, Mexico; xoseahernandez@uaemex.mx \\ 4 Escuela de Ingeniería Química, Universidad Popular Autónoma del Estado de Puebla, Puebla 72410, Mexico; \\ marioedgar.cordero@upaep.mx \\ * Correspondence: regalado@angel.umar.mx (A.R.-M.); pere@angel.umar.mx (E.P.-R.); \\ Tel.: +52-958-584-3057 (A.R.-M.); +52-958-584-3049 (E.P.-R.)
}

Received: 20 November 2020; Accepted: 15 December 2020; Published: 17 December 2020

check for updates

\begin{abstract}
Statistical analysis was applied to optimize the electrochemical mineralization of ibuprofen with two boron-doped diamond (BDD) electrodes in a continuous electrochemical flow reactor under recirculation batch mode. A central composite rotatable (CCR) experimental design was used to analyze the effect of initial $\mathrm{pH}$ (2.95-13.04), current intensity (2.66-4.34 A), and volumetric flow rate $(0.16-1.84 \mathrm{~L} / \mathrm{min})$ and further optimized by response surface methodology (RSM) to obtain the maximum mineralization efficiency and the minimum specific energy consumption. A 91.6\% mineralization efficiency $\left(E_{M}\right)$ of ibuprofen with a specific energy consumption $\left(E_{C}\right)$ of $4.36 \mathrm{KW} \mathrm{h/g}$ TOC within $7 \mathrm{~h}$ of treatment was achieved using the optimized operating parameters $\left(\mathrm{pH}_{0}=12.29\right.$, $I=3.26 \mathrm{~A}$, and $Q$ of $1 \mathrm{~L} / \mathrm{min})$. Experimental results of RSM were fitted via a third-degree polynomial regression equation having the performance index determination coefficients $\left(\mathrm{R}^{2}\right)$ of 0.8658 and 0.8468 for the $E_{M}$ and $E_{C}$, respectively. The reduced root-mean-square error (RMSE) was 0.1038 and 0.1918 for $E_{M}$ and $E_{C}$, respectively. This indicates an efficient predictive performance to optimize the operating parameters of the electrochemical flow reactor with desirability of 0.9999993. Besides, it was concluded that the optimized conditions allow to achieve a high percentage of ibuprofen mineralization (91.6\%) and a cost of 0.002 USD \$/L. Therefore, the assessed process is efficient for wastewater remediation."
\end{abstract}

Keywords: BDD electrodes; electrochemical flow reactor; mineralization of ibuprofen; numerical optimization approach; response surface methodology

\section{Introduction}

Over the last decade, water contamination has increased due to industrial activities. In this context, the pharmaceutical industry is of great concern since elements of its waste have been detected in the aquatic environment [1]. These contaminants are classified as emerging contaminants [2] and in concentrations up to $10 \mathrm{mg} / \mathrm{L}$ might have negative effects on human health [3]. Also, emerging contaminants can cause chronic toxicity and interference in the regulators of reproduction of vertebrates and invertebrates [4]. The most used anti-inflammatory drugs in Mexico 
include diclofenac, paracetamol, naproxen, and ibuprofen (IBU). These can be purchased without medical prescription, so their consumption is not regulated. All these compounds are considered emerging contaminants and IBU is one of the most worldwide consumed drugs [5]. IBU is an anti-inflammatory drug and it is prescribed for fever and to deal with inflammatory diseases like rheumatoid arthritis and osteoarthritis [3]. Different technologies have been evaluated to prevent the accumulation and destruction of IBU in the aquatic environment, such as physicochemical [6], biological [7], chemical [8,9], and advanced oxidation processes (AOPs) [10]. Table 1 presents the performance of other methods applied for the oxidation of IBU.

Table 1. Comparison of degradation performance of IBU of different methods.

\begin{tabular}{cccc}
\hline Method & Volume Treated $(\mathbf{m L})$ & Removal Efficiency (\%) & Reference \\
\hline Physicochemical & 100 & 50 & {$[6]$} \\
Biological & 130 & 83.3 & {$[7]$} \\
Ozonation & 200 & 99.0 & {$[8]$} \\
Ultraviolet $/ \mathrm{H}_{2} \mathrm{O}_{2}$ & 450 & 98.8 & {$[9]$} \\
Photo-Fenton & 80 & 40 & {$[10]$} \\
\hline
\end{tabular}

IBU mineralization has also been assessed by electro-oxidation. Such a process consists mainly of the hydroxyl radicals production at the electrode surface and therefore the efficiency of the process has been reported to depend on electrode type, applied electrical current and the effect of $\mathrm{pH}$ is controversial. Electro-oxidation is an electrochemical advanced oxidation process (EAOP) and it has been considered as a green technology for wastewater treatment since the main oxidant species, hydroxyl radicals, are produced without the further addition of dangerous chemicals [11]. To produce hydroxyl radicals on an electrode surface and perform an effective degradation and mineralization of organic pollutants, an adequate anode must be employed under appropriate reaction environments. In literature, the anodes of $\mathrm{Pt} / \mathrm{BDD}$ [3], Ti/ $\mathrm{Pt} / \mathrm{PbO}_{2}$ and Ti/BDD [12], multi-walled carbon nanotube [13], $\mathrm{Pt}$ [14], and PtRu [4] are anode materials that have been used to carry out the degradation of IBU. In previous studies on electrochemical degradation of IBU, the boron-doped diamond (BDD) anode has demonstrated to be a good alternative for the total organic carbon (TOC) removal from an IBU synthetic solution since $92 \%$ and $96 \%$ removal was obtained with the current density of $30 \mathrm{~mA} / \mathrm{cm}^{2}$ and $500 \mathrm{~mA} / \mathrm{cm}^{2}$, respectively, within $8 \mathrm{~h}$ of electrolysis on $200 \mathrm{~mL}$ of synthetic IBU solution $[3,12]$. Unfortunately, these works concluded that the high production cost of BDD electrodes makes the use of BDD anode not feasible for large-scale applications. Nevertheless, there are in the literature some important applications of BDD anode at a large-scale, which include the electro-oxidation of low-salinity reverse osmosis membrane concentrate $[15,16]$ and the removal of organic contaminants (such as IBU, atrazine, diclofenac, among others) from a secondary effluent of real wastewater in a divided electrochemical filter-press reactor with BDD anode $\left(40.8 \mathrm{~cm}^{2}\right.$ of an electroactive area), where the reactor was separated by a cation exchange membrane Ultrex CMI-7000. The main result of such investigation was that high removal of IBU achieved within $24 \mathrm{~h}$ of electrolysis time [17]. Although there are many studies about the degradation of IBU, only a few focuses on optimization. Such studies include the removal of IBU by absorption using mesoporous carbon aerogel [18], photooxidation of IBU using thin films of PAA/PAH/TiO 2 [19], nano-photocatalytic degradation of IBU by using Ultraviolet C/ZnO [20], IBU degradation by a three-dimensional electro-Fenton process [21], and sonoelectrochemical oxidation of IBU [22]. Thus, based on the literature survey, it can be concluded that the electrochemical degradation of IBU is feasible but needs to be optimized to reduce the overall cost of the process.

The main objective of this work was to conduct the statistical optimization of operating variables such as initial $\mathrm{pH}\left(\mathrm{pH}_{0}\right)$, current intensity $(I)$, and liquid volumetric flow rate $(Q)$, during the IBU electrochemical mineralization when using BDD electrodes as cathode and anode. To accomplish this, 
the response surface methodology (RSM) based on a central composite rotatable (CCR) experimental design was applied.

\section{Materials and Methods}

\subsection{Synthetic Solution of Ibuprofen}

All experiments were conducted with a solution containing IBU $(40 \mathrm{mg} / \mathrm{L}, 35 \mathrm{mg}$ of TOC/L) and $\mathrm{Na}_{2} \mathrm{SO}_{4}(0.1 \mathrm{M})$. This synthetic solution was prepared by adding the reagents into a reservoir with distilled water to dissolve the IBU. The IBU solution was homogenized by recirculating it for $2 \mathrm{~h}$ through the reaction system without applying any current intensity. It is worth mentioning that all solutions were prepared right before performing each experiment. The $\mathrm{pH}$ of the IBU solution was adjusted with $\mathrm{NaOH}(1 \mathrm{M})$ or $\mathrm{H}_{2} \mathrm{SO}_{4}(1 \mathrm{M})$. Both compounds were supplied in $97 \%$ purity by Meyer IBU ( $99 \%$ purity) was supplied by Sigma-Aldrich and $\mathrm{Na}_{2} \mathrm{SO}_{4}(99 \%$ purity) was supplied by Fluka. The chemical structure and physicochemical properties of IBU are summarized in Table 2.

Table 2. Physicochemical properties of IBU.

\begin{tabular}{|c|c|c|}
\hline Property & Value & Molecule of Ibuprofen \\
\hline Molar weight (g/mol) & 206.29 & $\mathrm{CH}_{3}$ \\
\hline Melting point $\left({ }^{\circ} \mathrm{C}\right)$ & $70-78$ & \\
\hline $\mathrm{p} K_{a}\left(\right.$ water at $\left.20^{\circ} \mathrm{C}\right)$ & 4.91 & \\
\hline $\log \left(K_{\text {ow }}\right)$ & 3.5 & $\mathrm{CH}_{3}$ \\
\hline Water solubility $(\mathrm{g} / \mathrm{L})$ at $25^{\circ} \mathrm{C}$ & 0.049 & \\
\hline Constant of Henry's law (atm/ $\left./ \mathrm{m}^{3} \mathrm{~mol}\right)$ & $1.5 \times 10^{-7}$ & \\
\hline$\lambda_{\max }(\mathrm{nm})$ & 221 & Chemical formula: $\mathrm{C}_{13} \mathrm{H}_{18} \mathrm{O}_{2}$ \\
\hline
\end{tabular}

Values were taken from references $[3,23,24]$.

\subsection{Experimental Setup}

Figure 1 shows the reaction system used to carry out the electrochemical mineralization of IBU.

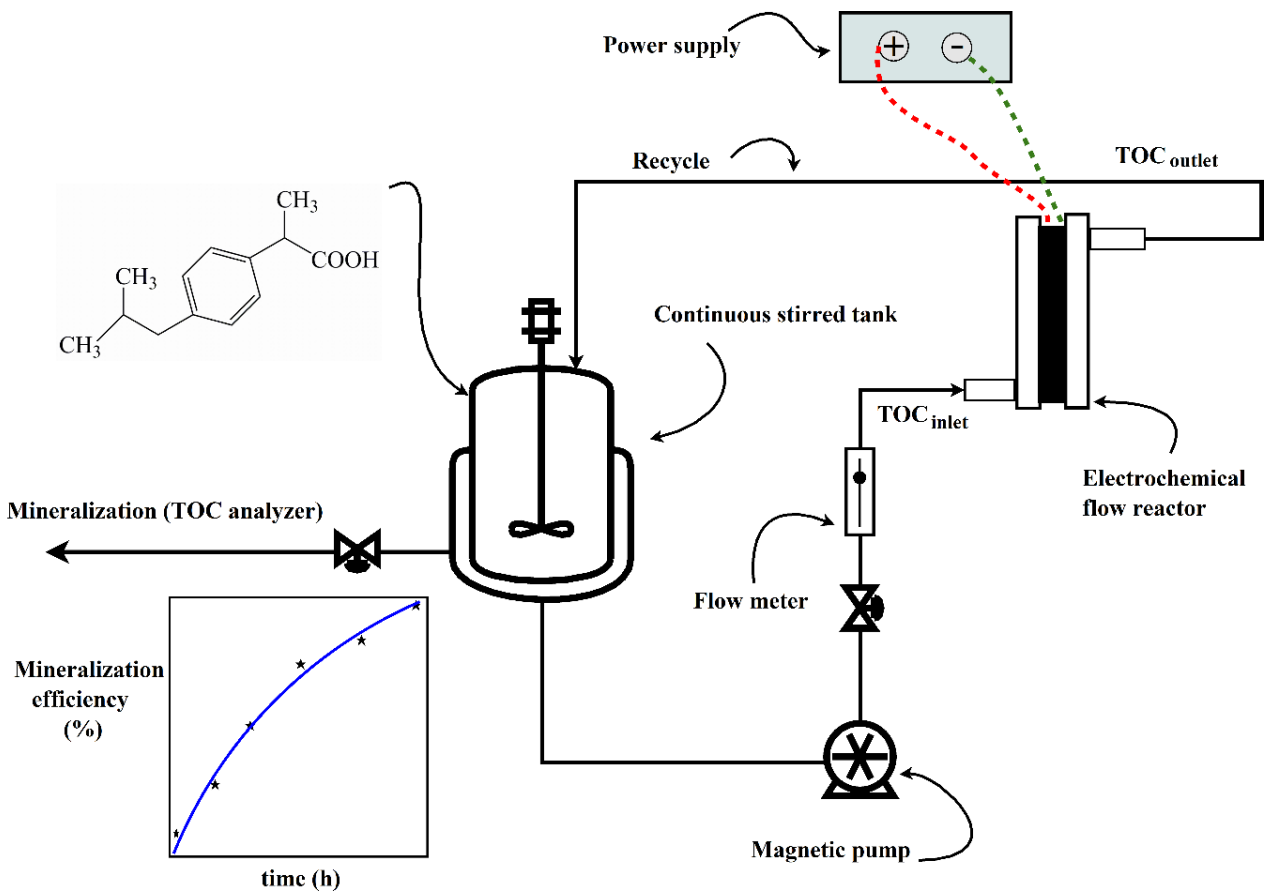

Figure 1. Experimental setup for the electrochemical mineralization of IBU in an Electrochemical Flow Reactor under recirculation batch mode. 
The experimental set-up is constituted by an electrochemical flow reactor (EFR) with a volume of $3.52 \times 10^{-5} \mathrm{~m}^{3}$, two BDD electrodes (a thickness of $5 \mu \mathrm{m}$ supported on $\mathrm{Nb}$ ) that are separated $1.1 \mathrm{~cm}$ from each other, a glass rotameter to measure the volumetric liquid flow rate, a pump to recirculate the synthetic solution and a reservoir to supply the IBU synthetic solution. The circulation pipe has an inner diameter of $1.27 \mathrm{~cm}$. Energy was supplied by a single output DC power supply. All experiments were carried out at $25^{\circ} \mathrm{C}$ and atmospheric pressure. A detailed description of the EFR has been previously reported [25].

\subsection{Electrochemical Mineralization of IBU}

The electrochemical mineralization of IBU was performed in the experimental set up depicted in Figure 1. In a typical experiment, $2.5 \mathrm{~L}$ of an IBU solution were loaded in a continuous stirred tank (see Figure 1). This solution was prepared as described in Section 2.1. The solution was then recirculated through the system by means of a pump. The liquid flowrate was regulated with a rotameter. In this way the IBU solution was continuously fed through the electrochemical flow reactor (EFR). The exit stream of the EFR was taken to the continuous stirred tank and recirculated again. The studied variables were $I, Q$, and $\mathrm{pH}_{0}$, according to Table 3 . The mineralization of IBU was verified by using TOC analysis (6001 TOC analyzer, Shimadzu, Instrumentation and Service in Analytica, S.A. de C.V., Calz, Mexico). For this purpose, samples at the beginning and after $7 \mathrm{~h}$ of electrolysis time were taken for each operating condition. All experiments were performed by duplicate. The reported mineralization efficiency and specific energy consumption is the average of the obtained results. The total number of experiments for the optimization process is presented in Table 4 .

Table 3. Values and levels of operating parameters.

\begin{tabular}{cccccc}
\hline \multirow{2}{*}{ Operating Factors } & \multicolumn{5}{c}{ Levels } \\
\cline { 2 - 6 } & $\mathbf{- \alpha}$ & $\mathbf{- 1}$ & $\mathbf{0}$ & $\mathbf{+ 1}$ & $\mathbf{+ \alpha}$ \\
\hline$X_{1}: \mathrm{pH}_{0}$ & 2.95 & 5.0 & 8.0 & 11.0 & 13.04 \\
$X_{2}: I(\mathrm{~A})$ & 2.66 & 3.0 & 3.5 & 4.0 & 4.34 \\
$X_{3}: Q(\mathrm{~L} / \mathrm{min})$ & 0.16 & 0.5 & 1.0 & 1.5 & 1.84 \\
\hline
\end{tabular}

Table 4. CCR experimental design for electrochemical mineralization of IBU.

\begin{tabular}{|c|c|c|c|c|c|c|c|c|}
\hline \multirow{2}{*}{ Run } & \multicolumn{3}{|c|}{ Authentic Values of Parameters } & \multicolumn{3}{|c|}{ Coded Values of Parameters } & \multicolumn{2}{|c|}{ Responses ( $\eta$ ) } \\
\hline & $X_{1}$ & $X_{2}$ & $X_{3}$ & $x_{1}$ & $x_{2}$ & $x_{3}$ & $\begin{array}{l}E_{M} \\
(\%)\end{array}$ & $\begin{array}{c}E_{C} \\
(\mathrm{KW} \mathrm{h} / \mathrm{g} \text { TOC) }\end{array}$ \\
\hline 1 & 5.0 & 3.0 & 0.5 & -1 & -1 & -1 & 60.67 & 5.25 \\
\hline 2 & 11.0 & 3.0 & 0.5 & +1 & -1 & -1 & 68.80 & 5.41 \\
\hline 3 & 5.0 & 4.0 & 0.5 & -1 & +1 & -1 & 57.94 & 12.11 \\
\hline 4 & 11.0 & 4.0 & 0.5 & +1 & +1 & -1 & 64.79 & 11.79 \\
\hline 5 & 5.0 & 3.0 & 1.5 & -1 & -1 & +1 & 53.22 & 8.27 \\
\hline 6 & 11.0 & 3.0 & 1.5 & +1 & -1 & +1 & 63.22 & 5.28 \\
\hline 7 & 5.0 & 4.0 & 1.5 & -1 & +1 & +1 & 72.86 & 10.51 \\
\hline 8 & 11.0 & 4.0 & 1.5 & +1 & +1 & +1 & 62.66 & 13.27 \\
\hline 9 & 2.95 & 3.5 & 1.0 & $-\alpha$ & 0 & 0 & 32.00 & 20.10 \\
\hline 10 & 13.04 & 3.5 & 1.0 & $+\alpha$ & 0 & 0 & 100.00 & 4.84 \\
\hline 11 & 8.0 & 2.66 & 1.0 & 0 & $-\alpha$ & 0 & 34.97 & 8.02 \\
\hline 12 & 8.0 & 4.34 & 1.0 & 0 & $+\alpha$ & 0 & 57.00 & 16.84 \\
\hline 13 & 8.0 & 3.5 & 0.16 & 0 & 0 & $-\alpha$ & 49.06 & 9.79 \\
\hline 14 & 8.0 & 3.5 & 1.84 & 0 & 0 & $+\alpha$ & 50.36 & 6.57 \\
\hline 15 & 8.0 & 3.5 & 1.0 & 0 & 0 & 0 & 50.45 & 11.06 \\
\hline 16 & 8.0 & 3.5 & 1.0 & 0 & 0 & 0 & 59.45 & 9.78 \\
\hline 17 & 8.0 & 3.5 & 1.0 & 0 & 0 & 0 & 50.36 & 13.32 \\
\hline 18 & 8.0 & 3.5 & 1.0 & 0 & 0 & 0 & 57.40 & 7.81 \\
\hline 19 & 8.0 & 3.5 & 1.0 & 0 & 0 & 0 & 53.87 & 10.94 \\
\hline 20 & 8.0 & 3.5 & 1.0 & 0 & 0 & 0 & 60.59 & 9.32 \\
\hline
\end{tabular}


In addition, the electrochemical mineralization of IBU was conducted at the optimal conditions in order to establish the TOC removal kinetics. For this experiment, $10 \mathrm{~mL}$ aliquots were taken every 25 min during $7 \mathrm{~h}$.

\subsection{Optimization Process}

Typically, an optimization process is conducted by changing one variable while keeping the others constant, until all variables have been investigated. However, this procedure implies a large number of experiments, and the combined effect of two variables or more might be missed [26].

The response surface methodology (RSM) is the preferred numerical tool to conduct a statistical analysis of the influence of process variables and to determine the optimum operating environments with a relatively small quantity of experiments. To accomplish this, the central composite rotatable (CCR) experimental design is a standard design of experiments (DOE) to conduct experimental planning and provide a sufficient amount of data for testing a lack of fit [27]. Central composite (CC) experimental design is based in two-level $(-1,+1)$ factorial designs ( $f u l l 2^{k}, k$ is the number of factors), augmented with $2 k$ centered points $(0)$ and $2 k$ axial points with two-levels $(-\alpha,+\alpha)$. A design is called rotatable when the variance of the predicted response at any point depends only on the distance of the point formed from the centered points of design and a CCR experimental design has five-levels for each factor. The rotatable design provides uniformity in the prediction error and it is achieved by proper choice of $\alpha\left(\alpha=2^{k / 4}\right)$ [28].

For this study, the values and levels of each operational parameter are summarized in Table 3. The $\mathrm{pH}$ is an important factor in wastewater treatment [29], and this is not the exemption. In this work, the studied $\mathrm{pH}$ range was established according to the hydrophobic and hydrophilic character of IBU. At $\mathrm{pH}$ lower than 4.9, IBU remains as a molecule, its solubility decreases and tends to precipitate [14]. At $\mathrm{pH}$ higher than 4.9, IBU hydrophilic character increases. Regarding liquid flow rate $(Q)$, in a previous study [25] with the same reactor albeit with another organic molecule, the optimal $Q$ was found to be in the interval of $0.5-1.5 \mathrm{~L} / \mathrm{min}$. Thus, it was decided to use a similar interval here. The values of the electrical current $(I)$ were selected within the typical range used in environmental applications, especially in electro-oxidation processes [30].

The operating parameters tested can be coded by Equation (1):

$$
x_{i}=\frac{X_{i}-X_{i, 0}}{\Delta X_{i}}
$$

Table 4 presents the authentic and coded values for the three operating variables chosen for the experimental design. The results obtained in terms of two measured response factors (dependent variables), namely mineralization efficiency $\left(E_{M}\right.$, response factor $\left.\eta_{1}\right)$, and specific energy consumption in $\mathrm{kW} \mathrm{h} /\left(\mathrm{g}\right.$ TOC) $\left(E_{C}\right.$, response factor $\left.\eta_{2}\right)$ are presented in Table 4.

In RSM the selected operational parameters must be analyzed as observed responses employing a third-degree polynomial function (Equation (2)),

$$
\begin{gathered}
\eta_{l}=\beta_{0}+\sum_{i=1}^{n} \beta_{i} x_{i}+\sum_{i=1}^{n} \beta_{i i} x_{i}^{2}+\sum_{i=1}^{n-1} \sum_{j=i+1}^{n} \beta_{i j} x_{i} x_{j}+\sum_{i=1}^{n-1} \beta_{i i} x_{i}^{3}+\sum_{i=1}^{n-1} \sum_{j=i+1}^{n} \beta_{i j} x_{i}^{2} x_{j} \\
+\sum_{i=1}^{n-2} \sum_{j=i+1}^{n-1} \sum_{m=j+1}^{n} \beta_{i j m} x_{i} x_{j} x_{m}+\varepsilon
\end{gathered}
$$

where $\beta$ values are the regression coefficients and $\varepsilon$ is the error. The $\beta$ parameters of the polynomial equation were computed by using step-wise regression. This type of regression is a combination of forward and backward regressions, starting with two forward steps. An analysis of variance (ANOVA) was applied to the experimental data for the determination of the model. The $\beta$ values were computed by regression analysis of data. The significant effect of $\beta$ values can be tested by means of a statistical 
significance test $(p \leq 0.05)$. Also, the coefficient of determination, $\mathbf{R}^{2}$, indicates the adjustment degree of the polynomial model.

In this work, the Design-Expert ${ }^{\circledR}$ V.10. software (Multion Consulting, S.A. de C.V, Calz, Mexico) was used to design the experiments, to perform, and to analyze the multiple regression, and to generate graphics of experimental data and results. Finally, the model accuracy for two responses was evaluated using the reduced root-mean-square error (RMSE). Performance index RMSE is represented by Equation (3) [31]:

$$
R M S E=\sqrt{\frac{1}{n} \sum_{n}\left(\frac{\eta_{I, \text { Pred }}-\eta_{I, \text { Exp }}}{\eta_{I, \text { Exp }}}\right)^{2}}
$$

where $\eta_{l \text {, Pred }}$ is the response obtained by the model, $\eta_{l, \text { Exp }}$ is the response obtained experimentally, and $n$ is the number of experiments.

\subsection{Analytic Procedure}

The mineralization efficiency of IBU was calculated employing Equation (4):

$$
E_{M}(\%)=\frac{T O C_{0}-T O C_{t}}{T O C_{0}} \times 100
$$

where $T O C_{0}$ and $T O C_{t}$ refer to the target total organic carbon concentrations before and after reaction time, respectively. The specific energy consumption $\left(E_{C}, \mathrm{~kW} \mathrm{h/g} \mathrm{TOC)}\right.$ was calculated according to Equation (5) [32]:

$$
E_{C}=\frac{E_{c e l l} \times I \times t}{V_{s} \times \Delta(T O C)_{E x p}}
$$

where $\triangle(T O C)_{E x p}$ is the removal of $\triangle T O C$ values at $t(\mathrm{~h}), I$ is the current intensity $(\mathrm{A}), E_{\text {cell }}$ is the average cell potential $(\mathrm{V})$, and $V_{s}$ is the volume of the treated synthetic wastewater (L). Finally, the real cost of the electrolysis process can be calculated by Equation (6) [33]:

$$
\text { Cost }=E_{C} \times T O C_{t=7 h} \times \frac{\$ M X P}{K W h}
$$

where Cost is the operation cost of the continuous electrochemical flow reactor and $\$ M X P / \mathrm{kW}$ is the cost per $\mathrm{kW}$ h. The average cost per $\mathrm{kW} h$ in Mexico to industries is $\$ 2.806 \mathrm{MXP}$ (CFE, Mexican Federal Electricity Commission) in November 2020.

\section{Results and Discussion}

\subsection{Assessment of Experimental Results with Design-Expert ${ }^{\circledR}$}

To explore the effects of the variables $\mathrm{pH}_{0}\left(X_{1}\right), I\left(X_{2}\right)$, and $Q\left(X_{3}\right)$ on mineralization efficiency $\left(\eta_{1}\right)$ and energy consumption $\left(\eta_{2}\right)$, the dependency of these variables was analyzed and modeled. From this analysis, a third-order model was employed to obtain a very good accuracy on both, modeling and optimization. In this particular case, a second-order model does not meet the criteria for a good predictive model. These criteria are the $p$-value of the model $\leq 0.05$, the $p$-value of the lack of fit $>0.1$, and the adjusted $\mathrm{R}^{2} \geq 0.8$ [34]. Third-order models that describe the variation of the selected responses are given by Equations (7) and (8):

$$
\begin{gathered}
\text { Inters of coded factors } \\
\eta_{1}=55.05+20.21 x_{1}+3.63 x_{2}+0.15 x_{3}-2.66 x_{1} x_{2}-1.87 x_{1} x_{3}+\cdots \\
x_{2} x_{3}+5.70 x_{1}^{2}-1.37 x_{2}^{2}-0.05 x_{3}^{2}-18.39 x_{1} x_{2}^{2} \\
\text { Inters of uncoded factors } \\
\eta_{1}=2337.09-296.38 X_{1}-1326.31 X_{2}-34.08 X_{3}+169.90 X_{1} X_{2}-1.25 X_{1} X_{3}+\cdots \\
12.81 X_{2} X_{3}+0.63 X_{1}^{2}+190.71 X_{2}^{2}-0.23 X_{3}^{2}-24.52 X_{1} X_{2}^{2}
\end{gathered}
$$




$$
\begin{gathered}
\text { Inters of coded factors } \\
\eta_{2}=10.41-3.02 x_{1}+2.62 x_{2}-0.19 x_{3}+0.65 x_{1} x_{2}-0.41 x_{1}^{2}+\cdots \\
+0.48 x_{2}^{2}-1.02 x_{3}^{2}+0.30 x_{1}^{2} x_{2}+2.97 x_{1} x_{2}^{2} \\
\text { Inters of uncoded factors } \\
\eta_{2}=-374.51+50.57 X_{1}+214.65 X_{2}+7.82 X_{3}-28.40 X_{1} X_{2}-0.28 X_{1}^{2}+\cdots \\
X_{2}^{2}-4.10 X_{3}^{2}+0.07 X_{1}^{2} X_{2}+3.96 X_{1} X_{2}^{2}
\end{gathered}
$$

From the ANOVA of results (Table 5), it can be observed that the two found third-order models were significant because they have low probability values [35] (0.0071 and 0.0044 for $E_{M}$ and $E_{C}$, respectively). To indicate an adequate signal for the model, adequate precision ratios greater than 4 must be achieved [36]. For these tested models $\left(E_{M}\right.$ and $\left.E_{C}\right)$, the adequate precision ratio of the models was 12.33 and 18.77, respectively. Additionally, in this study, the lack-of-fit $F$-test was statistically not significant because the values of Prob $>F$ ( 0.5370 and 0.5334 for $E_{M}$ and $E_{C}$, respectively) were greater than 0.005 , which implies a significant model correlation between variables $\left(X_{1}, X_{2}\right.$, and $\left.X_{3}\right)$ and responses $\left(\eta_{1}\right.$ and $\eta_{2}$ ). Moreover, the $R^{2}$ values were 0.8658 and 0.8468 for $\eta_{1}$ and $\eta_{2}$, respectively, which indicates a good model fitting [37].

Furthermore, the performance index RMSE for both responses $\left(\eta_{1}\right.$, and $\left.\eta_{2}\right)$ was computed by using Equation (3), where the values were 0.1038 and 0.1918 for mineralization efficiency and energy consumption, respectively. Small values of RMSE indicate that the developed models (Equations (7) and (8)) are in concordance with experimental results.

The parity plots shown in Figure 2 are evidence of the model suitability. Figure 2 shows there is a good correlation between experimental data and predicted values for both responses $\left(E_{M}(\%)\right.$ and $E_{C}$ $(\mathrm{KW} \mathrm{h} / \mathrm{g} \mathrm{TOC})$. Also, the coefficients of variation $(\mathrm{CV})$ values are lower $\left(12.82 \%\right.$ and $18.77 \%$ for $E_{M}$ and $E_{C}$, respectively). This indicates that the applied third-degree models are precise and reliable [38].

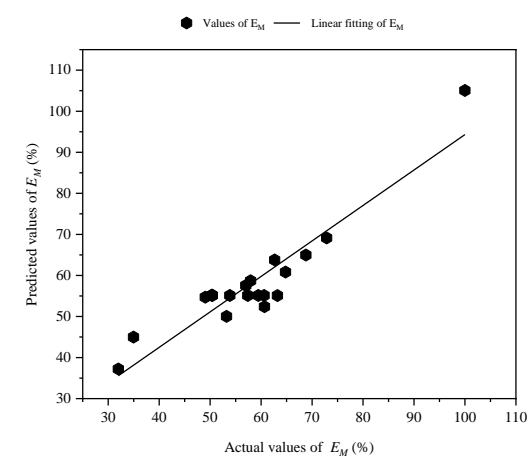

(a)

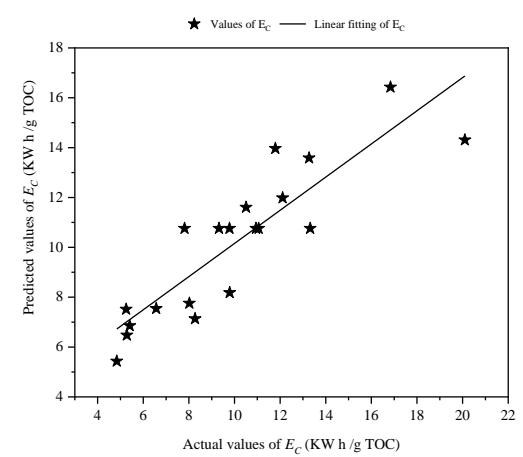

(b)

Figure 2. (a) Predicted versus experimental values plot for $E_{M}$ and (b) Predicted versus experimental values plot for $E_{C}$.

The coefficients of the tested cubic models (Equations (7) and (8)) indicate the relative effect of the independent factors $\left(X_{1}, X_{2}\right.$, and $\left.X_{3}\right)$ on responses $\left(E_{M}\right.$ and $\left.E_{C}\right)$. On the basis of the coefficients in Equation (7), it can be noted that the mineralization efficiency $\left(E_{M}\right)$ decreases with $\mathrm{pH}_{0}\left(X_{1}\right)$, $I\left(X_{2}\right)$, and $Q\left(X_{3}\right)$. A positive effect of the interaction between the variables of $\mathrm{pH}_{0}$ and $I\left(X_{1} X_{2}\right)$, and $\mathrm{pH}_{0}$ and $Q\left(X_{1} X_{3}\right)$ was also observed. Similarly, in Equation (8), it can be noted that the energy consumption $\left(E_{C}\right)$ increases with $\mathrm{pH}_{0}\left(X_{1}\right), I\left(X_{2}\right)$, and $Q\left(X_{3}\right)$, which indicates that an increase in $X_{1}$, $X_{2}$, and $\left(X_{3}\right)$ is not beneficial on response $E_{C}$. Also, the value of the coefficient of the unique interaction term $\left(X_{1} X_{2}\right)$ is negative, which indicates that the interaction term results in beneficial on response

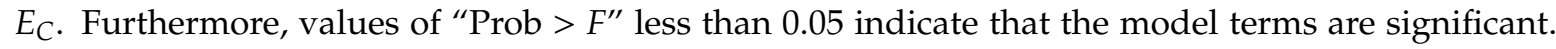
In the case of $E_{M}$, the terms $X_{1}, X_{1}{ }^{2}, X_{1} X^{2}{ }_{2}(p$-value $=0.0001,0.0173$, and 0.0015$)$ are the statistically significant model terms. Meanwhile, for the case of $E_{C}$ the terms $X_{1}, X_{2}, X_{1} X^{2}{ }_{2}$ ( $p$-value $=0.0029$, 0.0066 , and 0.0144 ) are the statistically significant model terms. Therefore, at this point, it can be said 
that $\mathrm{pH}_{0}$ and $I$ are the operational variables with the most significant effect on response variables, $E_{M}$ and $E_{C}$.

Table 5. ANOVA of the third-order models for $E_{M}\left(\eta_{1}\right)$ and $E_{C}\left(\eta_{2}\right)$.

\begin{tabular}{|c|c|c|c|c|c|c|}
\hline Source & Sum of Squares & Degree of Freedom & Mean Square & $F$-Value & Prob $>F$ & Remark \\
\hline \multicolumn{7}{|c|}{ Mineralization efficiency $\left(E_{M}\right), \eta_{1}(\%)$} \\
\hline Model & 312.03 & 10 & 321.20 & 5.81 & 0.0071 & \multirow[t]{12}{*}{ significant } \\
\hline$X_{1}$ & 2312 & 1 & 2312.00 & 41.83 & 0.0001 & \\
\hline$X_{2}$ & 180.07 & 1 & 180.07 & 3.26 & 0.1046 & \\
\hline$X_{3}$ & 0.34 & 1 & 0.34 & 0.00 & 0.9394 & \\
\hline$X_{1} X_{2}$ & 56.60 & 1 & 56.60 & 1.02 & 0.3379 & \\
\hline$X_{1} X_{3}$ & 28.05 & 1 & 28.04 & 0.51 & 0.4900 & \\
\hline$X_{2} X_{3}$ & 82.04 & 1 & 82.05 & 1.48 & 0.2541 & \\
\hline$X_{1}^{2}$ & 468.62 & 1 & 468.62 & 8.48 & 0.0173 & \\
\hline$X_{2}^{2}$ & 27.20 & 1 & 27.20 & 0.49 & 0.5007 & \\
\hline$X_{3}^{2}$ & 0.05 & 1 & 0.05 & 0.00 & 0.9742 & \\
\hline$X_{1} X_{2}^{2}$ & 1121.16 & 1 & 1121.16 & 20.28 & 0.0015 & \\
\hline Residual & 497.45 & 9 & 55.27 & & & \\
\hline \multirow{2}{*}{$\begin{array}{l}\text { Lack-of-fit } \\
\text { Pure } \\
\text { error }\end{array}$} & 397.88 & 4 & 99.47 & 4.99 & 0.5370 & \multirow[t]{3}{*}{ not significant } \\
\hline & 99.57 & 5 & 19.91 & & & \\
\hline Total & 3709.48 & 19 & & & & \\
\hline \multicolumn{7}{|c|}{$R^{2}=0.8658, \quad R_{a d j}^{2}=0.8168$} \\
\hline \multicolumn{7}{|c|}{ Energy consumption $\left(E_{C}\right), \eta_{2}(\mathrm{KW} \mathrm{h} / \mathrm{g}$ TOC $)$} \\
\hline Model & 185.59 & 9 & 20.62 & 6.14 & 0.0044 & \multirow[t]{11}{*}{ significant } \\
\hline$X_{1}$ & 51.61 & 1 & 51.61 & 15.38 & 0.0029 & \\
\hline$X_{2}$ & 39,07 & 1 & 39.07 & 11.64 & 0.0066 & \\
\hline$X_{3}$ & 0.51 & 1 & 0.51 & 0.15 & 0.7052 & \\
\hline$X_{1} X_{2}$ & 3.46 & 1 & 3.46 & 1.03 & 0.3340 & \\
\hline$X_{1}^{2}$ & 2.43 & 1 & 2.43 & 0.72 & 0.4148 & \\
\hline$X_{2}^{1}$ & 3.33 & 1 & 3.33 & 0.99 & 0.3429 & \\
\hline$X_{3}^{2}$ & 15.16 & 1 & 15.16 & 4.52 & 0.0595 & \\
\hline$X_{1}^{2} X_{2}^{3}$ & 0.31 & 1 & 0.31 & 0.09 & 0.7667 & \\
\hline$X_{1} X_{2}^{2}$ & 29.29 & 1 & 29.29 & 8.73 & 0.0144 & \\
\hline Residual & 33.56 & 10 & 3.36 & & & \\
\hline \multirow{3}{*}{$\begin{array}{l}\text { Lack-of-fit } \\
\text { Pure } \\
\text { error } \\
\text { Total }\end{array}$} & 16.12 & 10 & 3.22 & 0.92 & 0.5334 & \multirow[t]{3}{*}{ not significant } \\
\hline & 17.44 & 5 & 3.49 & & & \\
\hline & 219.16 & 19 & & & & \\
\hline
\end{tabular}

In addition, a perturbation plot (Figure 3 ) of the three tested operational variables $\left(\mathrm{pH}_{0}, I\right.$, and $\left.Q\right)$, also revealed that the $\mathrm{pH}_{0}$ is the most significant factor on response $E_{M}$, while the less significant factor was $Q$ (Figure 3a). Also, it can be concluded from Figure $3 b$ that the less significant factor on response $E_{C}$ was $x_{3}$, i.e., $Q$, because the slope of $E_{C}$ is small, while the most significant factors on objective function $E_{C}$ were $x_{1}$ and $x_{2}$ because the slope of $E_{C}$ is high.

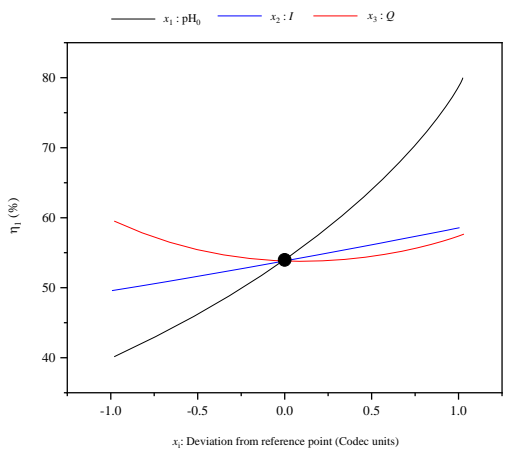

(a)

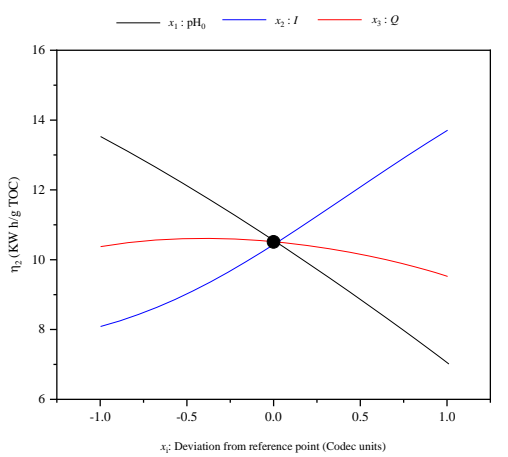

(b)

Figure 3. (a) Perturbation graphic for $\eta_{1}$ and (b) Perturbation graphic for $\eta_{2}$. 


\subsection{Optimization for Mineralization Efficiency and Energy Comsumption}

The determination of the optimal operational parameters to achieve the maximum mineralization of IBU with minimum specific energy consumption by applying a polynomial model of the responses ( $E_{M}$ and $E_{C}$ ) given by Equations (7) and (8) was assessed in Design-Expert ${ }^{\circledR}$ V. 10 software. It is worth mentioning that the Design Expert Software performs the multivariable optimization by using the Steepest Ascent method. The information entered to the software is given in Table 6. In order to conduct the optimization process, an objective for each factor and response must be selected from the software menu. This objective can be: maximize, minimize, target, within range, none (for responses only) and set to an exact value (factors only). Also, a minimum and a maximum limit must be provided for each parameter. In addition, a particular weight is assigned to each objective in order to adjust the shape of its particular desirability function. This is known as the importance of each objective and can be modified in relation to the other ones. The default for all objectives is that they are equally important and set as $(+++)$. In this case, the importance was set based on the results described in Section 3.1. From the perturbation plot (Figure 3), it can be concluded that the volumetric flow rate $(Q)$ does not exert a significant effect, thus $Q$ can be set at a value of $1 \mathrm{~L} / \mathrm{min}$ in the optimization criteria. This assumption $(Q=1 \mathrm{~L} / \mathrm{min})$ was made according to a previous work [25] because at this volumetric flow rate, the electrochemical flow reactor employed here has a high mass transport coefficient.

Table 6. Constrains criteria chosen for optimization of $E_{M}$ and $E_{C}$.

\begin{tabular}{cccccc}
\hline & \multicolumn{5}{c}{ Limits } \\
\hline Response & Objective & Min & Max & Unit & Importance \\
\hline $\mathrm{pH}_{0}$ & Is in range & 2.95 & 13.040 & dimensionless & +++ \\
$I$ & Is in range & 2.65 & 4.334 & $\mathrm{~A}$ & +++ \\
$Q$ & Set at 1 & 0.50 & 1.840 & $\mathrm{~L} / \mathrm{min}$ & ++ \\
$E_{M}$ & Maximize & 32.00 & 100.000 & $\%$ & +++ \\
$E_{C}$ & Minimize & 4.84 & 16.860 & $\mathrm{KW} \mathrm{h} / \mathrm{g}$ TOC & +++ \\
\hline
\end{tabular}

Surface graphics (Figure $4 \mathrm{~b}, \mathrm{~d}$ ) are the most important graphical representation in the RSM. These graphics can be obtained by plotting Equations (7) and (8). Such graphics allow us to evaluate, from a qualitative point of view, the behavior of the whole studied system. The 3D surface graphs (Figure $4 \mathrm{~b}, \mathrm{~d}$ ) were plotted by varying two parameters $\left(\mathrm{pH}_{0}\right.$ and $I$ ) at a certain time while the third parameter is at a central value (volumetric flow rate of $1 \mathrm{~L} / \mathrm{min}$ ). These graphs were employed to evaluate the effects of interaction between operational parameters. The $\mathrm{pH}_{0}$ and I interaction trajectories (Figure $4 \mathrm{a}, \mathrm{b}$ ) form a saddle area regarding $\mathrm{pH}_{0}$. This indicates that a $\mathrm{pH}_{0}$ variation at a specific $I$, exerts a major effect on mineralization efficiency $\left(E_{M}\right)$ in the studied region. The highest $E_{M}(89.5 \%)$ was obtained at high $\mathrm{pH}_{0}$ with low $E_{C}$. Although a relatively high $E_{M}$ was obtained at low $\mathrm{pH}_{0}$ (Figure $4 \mathrm{a}$ ), the specific energy consumption $\left(E_{C}\right)$ was higher than $E_{C}$ at a higher $\mathrm{pH}_{0}$. Similarly, a high effect of the $\mathrm{pH}_{0}$ and $I$ interaction on specific energy consumption (Figure $4 \mathrm{c}, \mathrm{d}$ ) can be noted. A low $E_{C}$ was obtained at high $\mathrm{pH}_{0}$, although a relatively lower $E_{C}$ could be obtained at lower $\mathrm{pH}_{0}$, the results suggest working at high $\mathrm{pH}_{0}$ because of desirability being 1 for both, $E_{M}$ and $E_{C}$ (Figure 4f). Also, in Figure 4a,c, saddle contour plots can be distinguished on the responses surfaces indicating that the interactions between the parameters are significant [39]. 


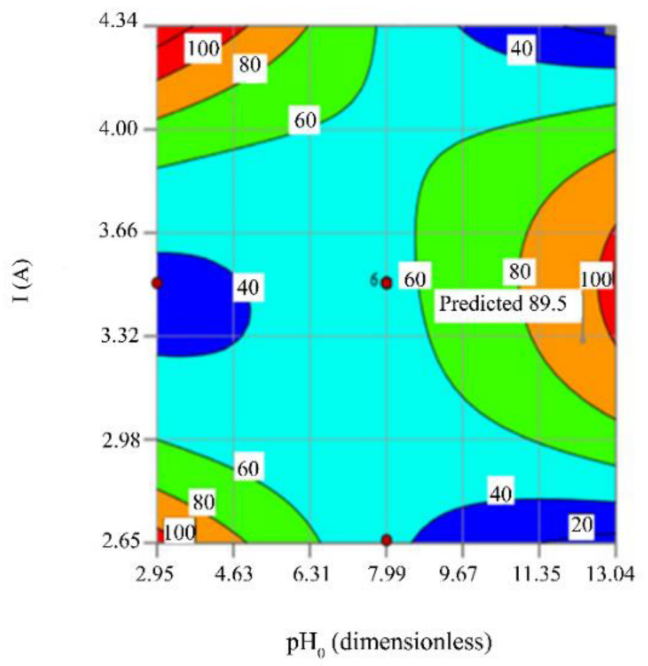

(a)

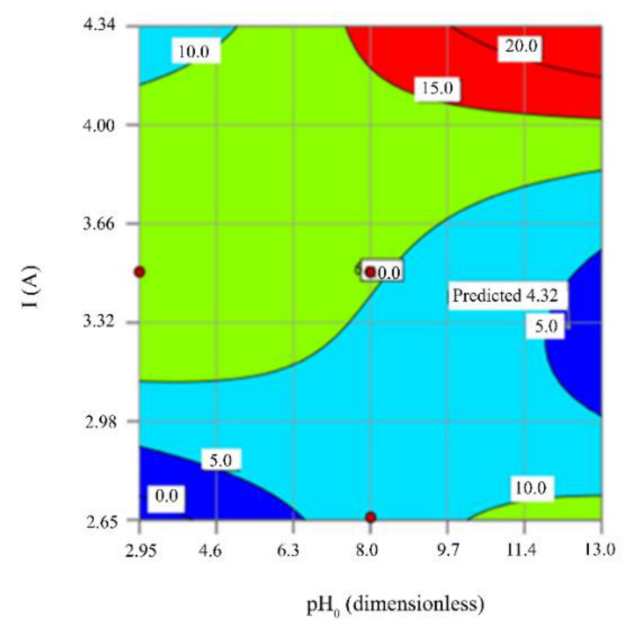

(c)

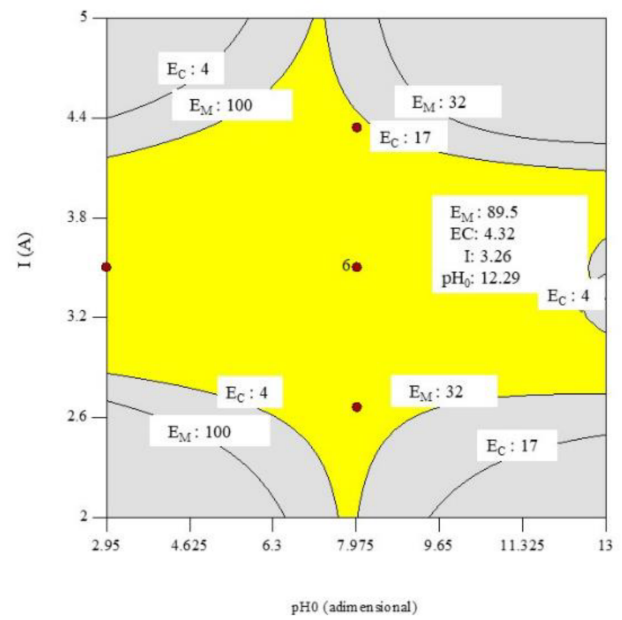

(e)

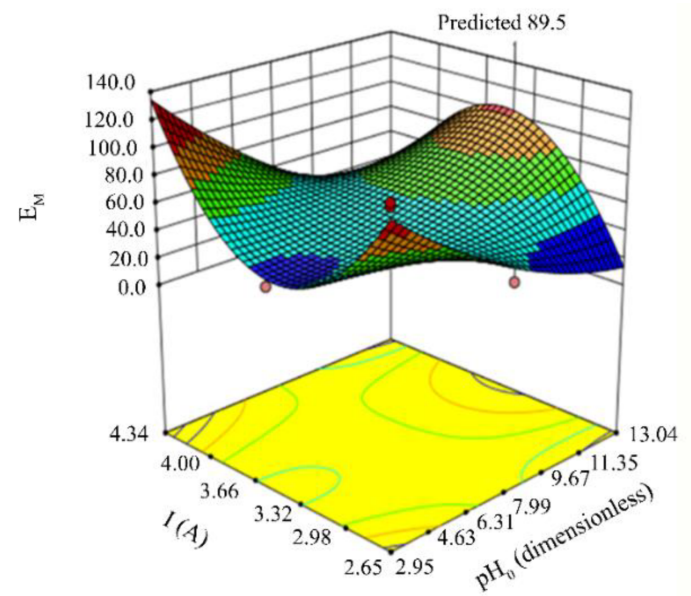

(b)

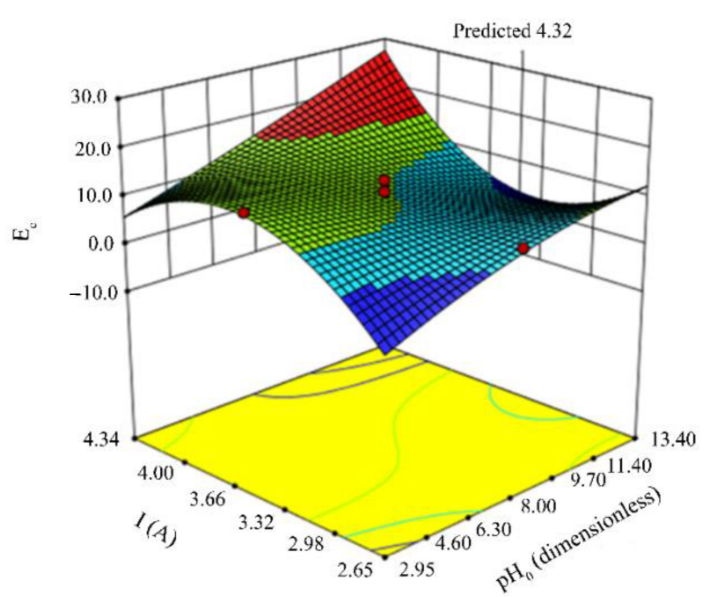

(d)

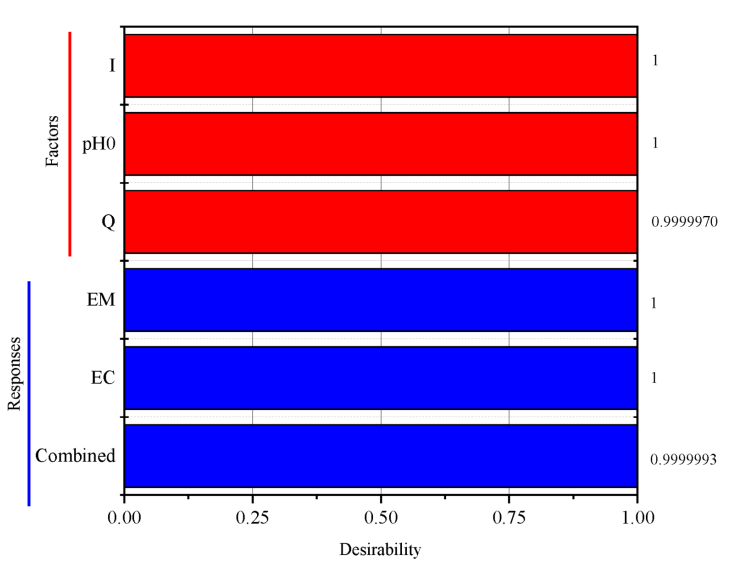

(f)

Figure 4. (a) Contour plot for response $\eta_{1}$ concerning $\mathrm{pH}_{0}$ and $I$; (b) $3 \mathrm{D}$ plot for response $\eta_{1} \mathrm{pH}_{0}$ and $I ;(\mathbf{c})$ Contour plot for response $\eta_{2}$ concerning $\mathrm{pH}_{0}$ and $I ;(\mathbf{d}) 3 \mathrm{D}$ plot for response $\eta_{2} \mathrm{pH}_{0}$ and I; (e) Optimal region plot, $\mathrm{pH}_{0}$ versus I; (f) Bar chart of desirability. Plots (a) to (b) were edited at a volumetric flow rate of $1 \mathrm{~L} / \mathrm{min}$. 
Figure $4 \mathrm{e}$ shows the feasible operational zone, which was plotted according to the constrained criteria (Table 6) of responses $\left(E_{M}\right.$ and $E_{C}$ ). The optimal $E_{M}$ and $E_{C}$ were $89.5 \%$ and $4.32 \mathrm{~kW} \mathrm{~h} / \mathrm{g} \mathrm{TOC}$, respectively, at an electrolysis time of $7 \mathrm{~h}$. The black lines in the overlay plots are assembling the adopted constraints criteria, the area that fulfills the constraints is in yellow, and the region that does not convene the constraints is in grey. The optimal region is enclosed by $\mathrm{pH}_{0}(0-13)$ and $I(2.60-4.40 \mathrm{~A})$ at the electrolysis time of $7 \mathrm{~h}$.

The multi-response optimization process has been assessed by the desirability function. The desirability function is defined in the range $[0,1]$. The desirability function indicates if the objectives were reached, for example, values near to 1 indicate that all objectives were met. Meanwhile, values nearly to 0 indicate that some objectives were not succeeded [40]. In this work, the optimal region value has the overall desirability value of 0.9999993 indicating that all objectives were succeeded (Figure 4f). Also, the obtained desirability is classified as excellent and acceptable [41]. Furthermore, the responses $\left(E_{M}\right.$ and $\left.E_{C}\right)$ have been simultaneously optimized using the developed models given by Equations (7) and (8).

\subsection{Model Validation}

The set of operating conditions with the highest value desirability was considered the optimum combination for required responses $\left(E_{M}\right.$ and $\left.E_{C}\right)$. To validate the models, three complementary experiments were carried out by setting the optimal operating parameters computed with the Design-Expert ${ }^{\circledR} \mathrm{V} .10$ software, namely $\mathrm{pH}_{0}$ of $12.29, I$ of $3.26 \mathrm{~A}$, and $Q$ of $1 \mathrm{~L} / \mathrm{min}$ for the initial total organic carbon of $35 \mathrm{mg}$ TOC/L. At these optimal conditions, the IBU mineralization percentage and

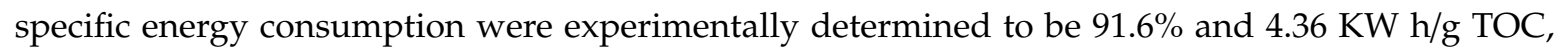

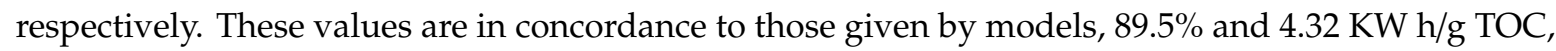
respectively. The relative error between experimental and models were $2.3 \%$ and $0.9 \%$, respectively. These results confirm that the developed models accurately describe the electrochemical mineralization of IBU on BDD electrodes (both cathode and anode) $[3,23,24]$ and the specific energy consumption.

The associated cost of the electrolysis process was estimated by means of Equation (6) at the optimal operating conditions of the electrochemical mineralization of IBU. The electricity cost for industrial use in Mexico is of $\$ 2.806 \mathrm{MXP} / \mathrm{kW}$ h. This energy was supplied by the Mexican Federal Electricity Commission ( $\mathrm{CFE}$, Comisión Federal de Electricidad). Based on this cost, the corresponding price of the green mineralization of IBU was $0.002 \mathrm{US} \$ / \mathrm{L}(\$ 0.035 \mathrm{MXP} / \mathrm{L}$, taking into account that 1 US\$ $\$ 20$ MXP).

Table 7 compares the results of this investigation with literature. The TOC removal percentage achieved in references (93.2\%) [42] and (96\%) [3] were greater than the TOC removal percentage $(91.6 \%)$ achieved in this work. However, the volume treated $(0.03$ and $0.2 \mathrm{~L}$, respectively) in literature was significantly smaller than the volume treated in this work $(2.5 \mathrm{~L})$. Additionally, the initial concentration of IBU $(20 \mathrm{mg} / \mathrm{L})$ in literature was lower than the initial concentration in this work $(40 \mathrm{mg} / \mathrm{L})$. Although, the volume $(3.0 \mathrm{~L})$ treated in reference [22] was greater than the volume treated in this work $(2.5 \mathrm{~L})$, the TOC removal $(84 \%)$ achieved was lower than the TOC removal percentage $(91.6 \%)$ achieved in this work. Furthermore, the specific energy consumption and associated cost $(0.057 \mathrm{~kW} \mathrm{~h} / \mathrm{L}$ and $0.003 \mathrm{US} \$ / \mathrm{L}$, respectively) in reference [22] were higher than the specific energy consumption and associated cost $(0.012 \mathrm{~kW} \mathrm{~h} / \mathrm{L}$ and $0.002 \mathrm{US} \$ / \mathrm{L}$, respectively) in this work. According to the obtained results of the green treatment used in this investigation, it can be concluded that this process is suitable for the elimination of emerging contaminants and specifically for IBU removal. 
Table 7. Green mineralization of IBU under various operational environments.

\begin{tabular}{|c|c|c|c|c|c|c|c|}
\hline \multirow{2}{*}{$\begin{array}{c}\begin{array}{c}\text { Operating } \\
\text { Environments }\end{array} \\
\text { Optimal }\end{array}$} & \multirow[b]{2}{*}{ Best } & \multirow[b]{2}{*}{ ET } & \multicolumn{4}{|c|}{ Main Results } & \multirow{2}{*}{ Reference } \\
\hline & & & $\begin{array}{l}V \\
(\mathrm{~L})\end{array}$ & $\begin{array}{c}\text { TOC } \\
(\%)\end{array}$ & $\begin{array}{c}E_{C} \\
(\mathrm{~kW} \mathrm{h/L)}\end{array}$ & $\begin{array}{c}\text { Cost } \\
\text { (US\$/L) }\end{array}$ & \\
\hline \multicolumn{8}{|l|}{$\begin{array}{c}40 \mathrm{mg} / \mathrm{L}, \mathrm{pH} \text { of } 12.29, \\
I \text { of } 3.26 \mathrm{~A}, Q \text { of }\end{array}$} \\
\hline $\begin{array}{l}1 \mathrm{~L} / \mathrm{min} \text { and } t_{e} \text { of } 7 \mathrm{~h} \text {, } \\
\text { flow reactor and batch } \\
\text { recirculation mode }\end{array}$ & - & BDD & 2.50 & 91.6 & 0.012 & 0.002 & This work \\
\hline 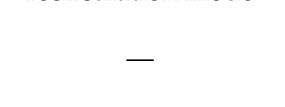 & $\begin{array}{c}20 \mathrm{mg} / \mathrm{L}, \mathrm{pH} \text { of } 6.0, J \text { of } \\
10 \mathrm{~mA} / \mathrm{cm}^{2}, t_{e} \text { of } 1 \mathrm{~h}, \\
\text { batch reactor }\end{array}$ & 1 & 0.03 & 93.2 & 0.013 & - & [42] \\
\hline - & $\begin{array}{c}20 \mathrm{mg} / \mathrm{L}, \mathrm{pH} \text { of } 3.0, J \text { of } \\
500 \mathrm{~mA} / \mathrm{cm}^{2}, t_{e} \text { of } 8 \mathrm{~h}, \\
\text { batch reactor }\end{array}$ & BDD & 0.20 & 96.0 & - & - & [3] \\
\hline- & $\begin{array}{c}361 \mathrm{mg} / \mathrm{L}, J \text { of } 30 \mathrm{~mA} / \mathrm{cm}^{2} \\
t_{e} \text { of } 6 \mathrm{~h} \text {, batch reactor }\end{array}$ & 2 & 0.20 & 87.0 & - & - & [12] \\
\hline- & $\begin{array}{c}2 \mathrm{mg} / \mathrm{L}, I \text { of } 2.3 \mathrm{~mA}, t_{e} \text { of } \\
2 \mathrm{~h} \text {, batch reactor }\end{array}$ & 3 & 0.7 & 67.2 & - & - & [13] \\
\hline $\begin{array}{c}10 \mathrm{mg} / \mathrm{L}, \mathrm{pH} \text { of } 6.6, \\
\text { I of } 5 \mathrm{~A}, t_{e} \text { of } 2 \mathrm{~h}, Q \text { of } \\
0.1 \mathrm{~L} / \mathrm{min}, \\
\text { batch reactor coupled } \\
\text { with ultrasonication } \\
\text { and batch } \\
\text { recirculation mode }\end{array}$ & - & 4 & 3.0 & 84.0 & 0.057 & 0.003 & [22] \\
\hline 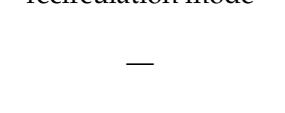 & $\begin{array}{c}50 \mathrm{mg} / \mathrm{L}, J \text { of } 50 \mathrm{~mA} / \mathrm{cm}^{2} \\
T \text { of } 298 \mathrm{~K}, t_{e} \text { of } 2 \mathrm{~h} \\
\text { batch reactor }\end{array}$ & PtRu & 0.1 & 82.0 & - & - & [4] \\
\hline
\end{tabular}

$t_{e}$ : Electrolysis time; ET: Electrode type $;{ }^{1}: \mathrm{Ti} / \mathrm{SnO}_{2}-\mathrm{Sb} / \mathrm{Ce}-\mathrm{PbO}_{2} ;{ }^{2}: \mathrm{Ti} / \mathrm{Pt} / \mathrm{PbO}_{2} ;{ }^{3}: \mathrm{AgZMWCNT} ;{ }^{4}: \mathrm{Ti} / \mathrm{PbO}{ }_{2}$.

\subsection{Kinetics of IBU Mineralization}

To determine the kinetic order of the electrochemical mineralization of IBU, an additional experiment was performed under the optimal operating conditions found in this investigation. Figure 5 depicts the kinetic behavior of the mineralization of IBU. TOC decay fitting was found satisfactory with a pseudo-zero order kinetics, $-\mathrm{d} C_{\mathrm{TOC}} / \mathrm{dt}=k_{0}$, where $\mathrm{k}_{0}$ is the pseudo-zero-order rate constant. From this analysis, the $k_{0}$ value TOC removal is $0.0824 \mathrm{mg}$ TOC/L min. This performance indicates a constant production of hydroxyl radicals.

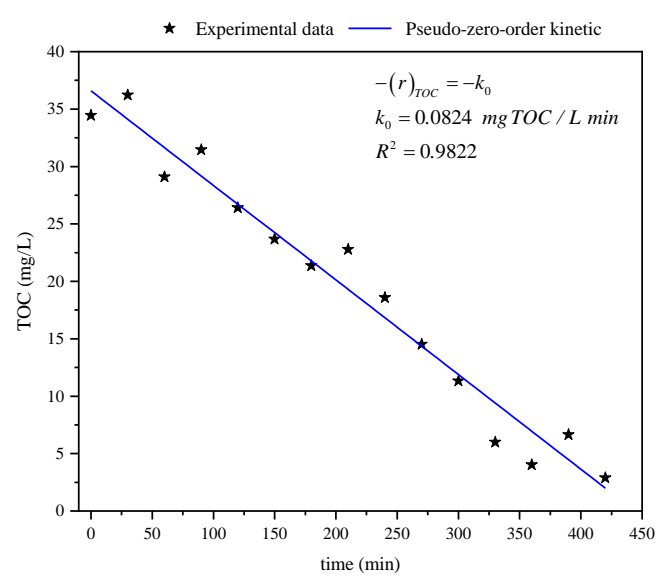

Figure 5. Decay kinetics of electrochemical mineralization of IBU. 
In Equation (9), $M$ is an electroactive site of BDD anode where the hydroxyl radicals are formed by the anodic oxidation of water (Equation (10)) [43], $\phi, \gamma, \delta$ and $n_{e}$ are stoichiometric coefficients. Equation (9) is the global mineralization reaction:

$$
\begin{gathered}
R+M(\bullet \mathrm{OH}) \rightarrow \phi \mathrm{CO}_{2}+\gamma \mathrm{H}_{2} \mathrm{O}+\delta \mathrm{H}^{+}+n_{e} e^{-} \\
\mathrm{R}=\mathrm{C}_{13} \mathrm{H}_{18} \mathrm{O}_{2} ; \quad M=B D D
\end{gathered}
$$

The appearance of intermediate compounds that are also being oxidized by hydroxyl radicals attack is expected, however. By this means, two plausible mineralization routes have been proposed [42]. In any of these two proposed reaction routes, the first step is the hydroxylation of IBU albeit at different carbon positions. In both routes, the degradation of the intermediates occurs by further hydroxylation and decarboxylation until carboxylic acids are produced and these are further degraded down to $\mathrm{CO}_{2}$ and water by ${ }^{\bullet} \mathrm{OH}$ attack:

$$
\mathrm{BDD}+\mathrm{H}_{2} \mathrm{O} \rightarrow \mathrm{BDD}+{ }^{\bullet} \mathrm{OH}+\mathrm{H}^{+}+e^{-}
$$

To prove that the electrochemical mineralization of IBU was carried out by diffusion control (mass transfer from the bulk solution to the surface of the electrode), the relative magnitude of limiting current density $J_{\text {Lim }}$, as seen in Equations (11) and (12), and applied current density $\left(J_{\text {Appl }}\right)$ [4] can be compared. If $J_{A p p l}<J_{\text {Lim }}$, the electrochemical process is currently controlled otherwise the electrochemical process is controlled by diffusion:

$$
\begin{gathered}
J_{\text {Lim }}=n_{e} F K_{m} C_{0} \\
\ln \left(\frac{\text { TOC }_{t}}{\text { TOC }_{0}}\right)=-k_{m}\left(\frac{A}{V_{s}} t\right)
\end{gathered}
$$

where $n_{e}$ is the number of electrons, $F$ is the Faraday constant, $k_{m}$ is the average mass transfer coefficient, $C_{0}$ is the initial concentration of IBU, $A$ is the electrode area, and $V_{\mathrm{s}}$ is the total volume of treated synthetic solution in batch mode.

The value of the mass transfer coefficient $k_{m}$ was of $2.22 \times 10^{-6} \mathrm{~m} / \mathrm{s}$. Also, the $J_{A p p l}$ value $\left(109.0 \mathrm{~mA} / \mathrm{cm}^{2}\right)$ was greater than $J_{\text {Lim }}$ value $\left(2.74 \mathrm{~mA} / \mathrm{cm}^{2}\right)$. Hence, the greener process employed in this investigation was controlled by diffusion because has a higher diffusion rate and higher mineralization efficiency of IBU [12], which implies that the diffusive flux is directly proportional to the steepness of the concentration gradient.

\section{Conclusions}

In this work, the electrochemical mineralization of IBU was successfully carried out with two BDD electrodes (both cathode and anode) in an electrochemical flow reactor (EFR) under recirculation batch mode.

The optimization of operational variables was successfully achieved through numerical optimization based on DOE. The maximum mineralization efficiency $\left(E_{M}\right)$ was $91.6 \%$ with a minimum specific energy consumption $\left(E_{C}\right)$ of $4.36 \mathrm{KW} \mathrm{h/(g} \mathrm{TOC).} \mathrm{These} \mathrm{values} \mathrm{were} \mathrm{achieved} \mathrm{when} \mathrm{EFR}$ operates under a $\mathrm{pH}_{0}$ of $12.29, I$ of $3.26 \mathrm{~A}$, and $Q$ of $1 \mathrm{~L} / \mathrm{min}$ at an electrolysis time of $7 \mathrm{~h}$.

The mathematical models developed in this work allow the prediction of $E_{M}$ and $E_{C}$ as a function of $\mathrm{pH}_{0}, I$, and $Q$ under-tested experimental conditions. Additionally, the most significant factors were found to be $\mathrm{pH}_{0}$ and $I$. These models are:

$$
\left(\begin{array}{c}
E_{M}=2337.09-296.38 X_{1}-1326.31 X_{2}-34.08 X_{3}+169.90 X_{1} X_{2}-1.25 X_{1} X_{3}+\cdots \\
12.81 X_{2} X_{3}+0.63 X_{1}^{2}+190.71 X_{2}^{2}-0.23 X_{3}^{2}-24.52 X_{1} X_{2}^{2} \\
E_{C}=-374.51+50.57 X_{1}+214.65 X_{2}+7.82 X_{3}-28.40 X_{1} X_{2}-0.28 X_{1}^{2}+\cdots \\
-29.79 X_{2}^{2}-4.10 X_{3}^{2}+0.07 X_{1}^{2} X_{2}+3.96 X_{1} X_{2}^{2}
\end{array}\right)
$$


BDD electrodes (both cathode and anode) allow one to conduct IBU mineralization with a relatively

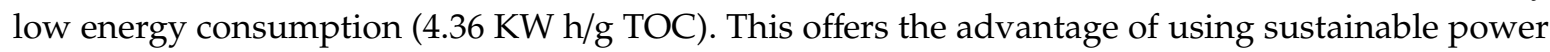
energy, i.e., solar batteries. Thus, the studied process here is a green treatment to eliminate emerging contaminants from wastewater.

Author Contributions: Writing-original draft preparation, A.R.-M.; data curation, A.R.-M., M.R. and E.P.-R.; writing-review and editing, A.R.-M., J.A.H.-S., M.E.C., E.P.-R., C.E.-V., R.N. and R.R.; methodology, A.R.-M.; formal analysis, E.P.-R., R.N. and A.R.-M.; investigation, E.P.-R., M.R. and A.R.-M.; supervision, E.P.-R. and A.R.-M.; resources, E.P.-R.; project administration, E.P.-R.; visualization, E.P.-R.; conceptualization, R.R. and C.E.; software, A.R.-M. and M.E.C. All authors have read and agreed to the published version of the manuscript.

Funding: Martín Ruiz Martínez was funded by Mexican Council of Science and Technology (CONACyT) to conduct his master studies at Universidad del Mar, scholarship No.791495. Alejandro Regalado Méndez was funded by CONACyT to conduct his sabbatical position at Universidad Autónoma del Estado de México, grand number 740588 .

Conflicts of Interest: The authors declare no conflict of interest.

\section{Nomenclature}

\begin{tabular}{|c|c|}
\hline Symbol & Meaning \\
\hline$A$ & Electrode area, $32 \mathrm{~cm}^{2}$ \\
\hline C & Concentration of ibuprofen, $\mathrm{mg} / \mathrm{L}$ \\
\hline Cost & Operation cost of the continuous electrochemical flow reactor, US\$/L \\
\hline$E_{M}$ & Mineralization efficiency, \% \\
\hline$E_{C}$ & Specific energy consumption, $\mathrm{KW} \mathrm{h/g}$ of TOC \\
\hline$E_{\text {cell }}$ & Average cell potential, V \\
\hline$F$ & Faraday constant, 96,487 C/mol \\
\hline$I$ & Current intensity, A \\
\hline$J$ & Current density, $\mathrm{mA} / \mathrm{cm}^{2}$ \\
\hline$K_{\mathrm{ow}}$ & Octanol-water partition coefficient, dimensionless \\
\hline$k_{m}$ & Medium mass transfer coefficient, $\mathrm{m} / \mathrm{s}$ \\
\hline$n_{e}$ & Number of electrons, 66 \\
\hline $\mathrm{pH}$ & Logarithmic scale of acidity or basicity, dimensionless \\
\hline$x_{i}$ & Codec operating parameters, dimensionless \\
\hline $\mathrm{p} K_{a}$ & Negative base-10 logarithm of the acid dissociation constant, $\mathrm{mg} / \mathrm{L}$ \\
\hline$Q$ & Volumetric flow rate, $\mathrm{L} / \mathrm{min}$ \\
\hline$t$ & Time, h \\
\hline$t_{e}$ & Electrolysis time, $\mathrm{h}$ \\
\hline$V_{\mathrm{s}}$ & Total volume of the treated solution in batch mode, $\mathrm{L}$ \\
\hline \multicolumn{2}{|l|}{ Greek letters } \\
\hline$\beta$ & Coefficients of the statistical model \\
\hline$\gamma$ & Stoichiometric coefficient, 24 \\
\hline$\delta$ & Stoichiometric coefficient, 66 \\
\hline$\varepsilon$ & Error \\
\hline$\eta$ & Responses \\
\hline$\lambda$ & Wavelength of adsorbate molecule, $\mathrm{nm}$ \\
\hline$\phi$ & Stoichiometric coefficient, 13 \\
\hline \multicolumn{2}{|l|}{ Acronyms } \\
\hline ANOVA & Analysis of variance \\
\hline AOPs & Advanced Oxidation Processes \\
\hline AgZMWCNT & Silver-modified zeolite-multiwalled-carbon nanotubes \\
\hline BDD & Boron-doped diamond \\
\hline CCR & Central composite rotatable \\
\hline CV & Coefficient of variance \\
\hline EC & Emergent contaminant \\
\hline EAOPs & Electrochemical advanced oxidation processes \\
\hline
\end{tabular}




$\begin{array}{ll}\text { EFR } & \text { Electrochemical flow reactor } \\ F & \text { Fisher distribution } \\ \text { IBU } & \text { Ibuprofen } \\ \text { MWCNT } & \text { Multiwalled-carbon nanotubes } \\ M & \text { Electroactive site of BDD electrode where the hydroxyl radicals are formed } \\ \text { PAA } & \text { Polyacrylic acid } \\ \text { PAH } & \text { Polyallylamine hydrochloride } \\ R & \text { Organic compound to be mineralized } \\ \text { RSM } & \text { Response surface methodology } \\ \text { RMSE } & \text { Reduced root-mean-square error } \\ \text { TOC } & \text { Total organic carbon } \\ \text { TiO } 2 & \text { Titanium dioxide } \\ \text { UVC } & \text { Medium pressure Hg vapor lamp } \\ X_{i} & \text { Operating parameters } \\ \text { ZnO } & \text { Zinc oxide } \\ \bullet \text { OH } & \text { Hydroxyl radical } \\ \text { Subscripts } & \\ \text { Appl } & \text { Applied } \\ \text { Exp } & \text { Experimental } \\ i & \text { Variable number } \\ j & \text { Variable different to } i \\ k & \text { Operating factor } \\ l & \text { Response number, } 1 \text { or } 2 \\ \text { Lim } & \text { Limit } \\ m & \text { Variable different to } i \text { and } j \\ \text { Pred } & \text { Predicted } \\ 0 & \text { Initial } \\ \text { max } & \text { Maximum } \\ & \end{array}$

\section{References}

1. Skoczko, I.; Ofman, P.; Szatylowicz, E. Using Artificial Neural Networks for Modeling Wastewater Treatment in Small Wastewater Treatment Plant. Annu. Set Environ. Prot. 2016, 8, 493-506.

2. Daughton, C.G. Non-Regulated Water Contaminants: Emerging Research. Environ. Impact Assess. Rev. 2004, 24, 711-732. [CrossRef]

3. Ambuludi, S.L.; Panizza, M.; Oturan, N.; Özcan, A.; Oturan, M.A. Kinetic Behavior of Anti-Inflammatory Drug Ibuprofen in Aqueous Medium during Its Degradation by Electrochemical Advanced Oxidation. Environ. Sci. Pollut. Res. 2013, 20, 2381-2389. [CrossRef]

4. Chang, C.-F.; Chen, T.-Y.; Chin, C.-J.M.; Kuo, Y.-T. Enhanced Electrochemical Degradation of Ibuprofen in Aqueous Solution by PtRu Alloy Catalyst. Chemosphere 2017, 175, 76-84. [CrossRef]

5. Comber, S.; Gardner, M.; Sörme, P.; Leverett, D.; Ellor, B. Active Pharmaceutical Ingredients Entering the Aquatic Environment from Wastewater Treatment Works: A Cause for Concern? Sci. Total Environ. 2018, 613-614, 538-547. [CrossRef]

6. Phasuphan, W.; Praphairaksit, N.; Imyim, A. Removal of Ibuprofen, Diclofenac, and Naproxen from Water Using Chitosan-Modified Waste Tire Crumb Rubber. J. Mol. Liq. 2019, 294, 111554. [CrossRef]

7. Marchlewicz, A.; Guzik, U.; Smułek, W.; Wojcieszyńska, D. Exploring the Degradation of Ibuprofen by Bacillus Thuringiensis B1(2015b): The New Pathway and Factors Affecting Degradation. Molecules 2017, 22, 1676. [CrossRef]

8. Quero-Pastor, M.J.; Garrido-Perez, M.C.; Acevedo, A.; Quiroga, J.M. Ozonation of Ibuprofen: A Degradation and Toxicity Study. Sci. Total Environ. 2014, 466-467, 957-964. [CrossRef]

9. Su, R.; Chai, L.; Tang, C.; Li, B.; Yang, Z. Comparison of the Degradation of Molecular and Ionic Ibuprofen in a UV/H2O2 System. Water Sci. Technol. 2018, 77, 2174-2183. [CrossRef]

10. Méndez-Arriaga, F.; Esplugas, S.; Giménez, J. Degradation of the Emerging Contaminant Ibuprofen in Water by Photo-Fenton. Water Res. 2010, 44, 589-595. [CrossRef] 
11. Sahmi, A.; Omeiri, S.; Bensadok, K.; Trari, M. Electrochemical Properties of the Scheelite BaWO4 Prepared by Co-Precipitation: Application to Electro-Photocatalysis of Ibuprofen Degradation. Mater. Sci. Semicond. Process. 2019, 91, 108-114. [CrossRef]

12. Ciríaco, L.; Anjo, C.; Correia, J.; Pacheco, M.J.; Lopes, A. Electrochemical Degradation of Ibuprofen on $\mathrm{Ti} / \mathrm{Pt} / \mathrm{PbO} 2$ and Si/BDD Electrodes. Electrochim. Acta 2009, 54, 1464-1472. [CrossRef]

13. Motoc, S.; Remes, A.; Pop, A.; Manea, F.; Schoonman, J. Electrochemical Detection and Degradation of Ibuprofen from Water on Multi-Walled Carbon Nanotubes-Epoxy Composite Electrode. J. Environ. Sci. 2013, 25, 838-847. [CrossRef]

14. Thokchom, B.; Kim, K.; Park, J.; Khim, J. Ultrasonically Enhanced Electrochemical Oxidation of Ibuprofen. Ultrason. Sonochem. 2015, 22, 429-436. [CrossRef] [PubMed]

15. Van Hege, K.; Verhaege, M.; Verstraete, W. Electro-Oxidative Abatement of Low-Salinity Reverse Osmosis Membrane Concentrates. Water Res. 2004, 38, 1550-1558. [CrossRef] [PubMed]

16. Zhou, M.; Liu, L.; Jiao, Y.; Wang, Q.; Tan, Q. Treatment of High-Salinity Reverse Osmosis Concentrate by Electrochemical Oxidation on BDD and DSA Electrodes. Desalination 2011, 277, 201-206. [CrossRef]

17. Garcia-Segura, S.; Keller, J.; Brillas, E.; Radjenovic, J. Removal of Organic Contaminants from Secondary Effluent by Anodic Oxidation with a Boron-Doped Diamond Anode as Tertiary Treatment. J. Hazard. Mater. 2015, 283, 551-557. [CrossRef]

18. Abolhasani, S.; Ahmadpour, A.; Rohani Bastami, T.; Yaqubzadeh, A. Facile Synthesis of Mesoporous Carbon Aerogel for the Removal of Ibuprofen from Aqueous Solution by Central Composite Experimental Design (CCD). J. Mol. Liq. 2019, 281, 261-268. [CrossRef]

19. Vebber, M.C.; da Silva Crespo, J.; Giovanela, M. Self-Assembled Thin Films of PAA/PAH/TiO 2 for the Photooxidation of Ibuprofen. Part I: Optimization of Photoactivity Using Design of Experiments and Surface Response Methodology. Chem. Eng. J. 2019, 360, 1447-1458. [CrossRef]

20. Rastkari, N.; Eslami, A.; Nasseri, S.; Piroti, E.; Asadi, A. Optimizing Parameters on Nanophotocatalytic Degradation of Ibuprofen Using UVC/ZnO Processes by Response Surface Methodology. Polish J. Environ. Stud. 2017, 26, 785-794. [CrossRef]

21. Mohammadi, H.; Bina, B.; Ebrahimi, A. A Novel Three-Dimensional Electro-Fenton System and Its Application for Degradation of Anti-Inflammatory Pharmaceuticals: Modeling and Degradation Pathways. Process Saf. Environ. Prot. 2018, 117, 200-213. [CrossRef]

22. Tran, N.; Drogui, P.; Nguyen, L.; Brar, S.K. Optimization of Sono-Electrochemical Oxidation of Ibuprofen in Wastewater. J. Environ. Chem. Eng. 2015, 3 Pt A, 2637-2646. [CrossRef]

23. Das, S.K.; Kahali, N.; Bose, A.; Khanam, J. Physicochemical Characterization and in Vitro Dissolution Performance of Ibuprofen-Captisol ${ }^{\circledR}$ (Sulfobutylether Sodium Salt of $\left.\beta-C D\right)$ Inclusion Complexes. J. Mol. Liq. 2018, 261, 239-249. [CrossRef]

24. Fröhlich, A.C.; Ocampo-Pérez, R.; Diaz-Blancas, V.; Salau, N.P.G.; Dotto, G.L. Three-Dimensional Mass Transfer Modeling of Ibuprofen Adsorption on Activated Carbon Prepared by Sonication. Chem. Eng. J. 2018, 341, 65-74. [CrossRef]

25. Regalado-Méndez, A.; Mentado-Morales, J.; Vázquez, C.E.; Martínez-Villa, G.; Cordero, M.E.; Zárate, L.G.; Skogestad, S.; Peralta-Reyes, E. Modeling and Hydraulic Characterization of a Filter-Press-Type Electrochemical Reactor by Using Residence Time Distribution Analysis and Hydraulic Indices. Int. J. Chem. React. Eng. 2018, 16, 1-15. [CrossRef]

26. Zhang, C.; Yang, L.; Rong, F.; Fu, D.; Gu, Z. Boron-Doped Diamond Anodic Oxidation of Ethidium Bromide: Process Optimization by Response Surface Methodology. Electrochim. Acta 2012, 64, 100-109. [CrossRef]

27. Wei, J.; Zhu, X.; Ni, J. Electrochemical Oxidation of Phenol at Boron-Doped Diamond Electrode in Pulse Current Mode. Electrochim. Acta 2011, 56, 5310-5315. [CrossRef]

28. Yahiaoui, I.; Aissani-Benissad, F.; Fourcade, F.; Amrane, A. Response Surface Methodology for the Optimization of the Electrochemical Degradation of Phenol on $\mathrm{Pb} / \mathrm{Pbo} 2$ Electrode. Environ. Prog. Sustain. Energy 2012, 31, 515-523. [CrossRef]

29. Zhou, M.; Särkkä, H.; Sillanpää, M. A Comparative Experimental Study on Methyl Orange Degradation by Electrochemical Oxidation on BDD and MMO Electrodes. Sep. Purif. Technol. 2011, 78, 290-297. [CrossRef]

30. Maldonado, S.; Rodrigo, M.; Cañizares, P.; Roa, G.; Barrera, C.; Ramirez, J.; Sáez, C. On the Degradation of $17-\beta$ Estradiol Using Boron Doped Diamond Electrodes. Processes 2020, 8, 710. [CrossRef] 
31. Viana, D.F.; Salazar-Banda, G.R.; Leite, M.S. Electrochemical Degradation of Reactive Black 5 with Surface Response and Artificial Neural Networks Optimization Models. Sep. Sci. Technol. 2018, 53, 2647-2661. [CrossRef]

32. Brillas, E.; Sirés, I.; Oturan, M.A. Electro-Fenton Process and Related Electrochemical Technologies Based on Fenton's Reaction Chemistry. Chem. Rev. 2009, 109, 6570-6631. [CrossRef]

33. Barrera-Díaz, C.E.; Frontana-Uribe, B.A.; Rodríguez-Peña, M.; Gomez-Palma, J.C.; Bilyeu, B. Integrated Advanced Oxidation Process, Ozonation-Electrodegradation Treatments, for Nonylphenol Removal in Batch and Continuous Reactor. Catal. Today 2018, 305, 108-116. [CrossRef]

34. Rheem, S.; Rheem, I.; Oh, S. Response Surface Methodology Using a Fullest Balanced Model: A Re-Analysis of a Dataset in the Korean Journal for Food Science of Animal Resources. Korean J. Food Sci. Anim. Resour. 2017, 37, 139-146. [CrossRef]

35. Muhamad, M.H.; Abdullah, S.R.S.; Mohamad, A.B.; Abdul Rahman, R.; Hasan Kadhum, A.A. Application of Response Surface Methodology (RSM) for Optimisation of COD, NH3-N and 2,4-DCP Removal from Recycled Paper Wastewater in a Pilot-Scale Granular Activated Carbon Sequencing Batch Biofilm Reactor (GAC-SBBR). J. Environ. Manag. 2013, 121, 179-190. [CrossRef]

36. Aziz, S.Q.; Aziz, H.A.; Yusoff, M.S.; Bashir, M.J.K. Landfill Leachate Treatment Using Powdered Activated Carbon Augmented Sequencing Batch Reactor (SBR) Process: Optimization by Response Surface Methodology. J. Hazard. Mater. 2011, 189, 404-413. [CrossRef]

37. Regalado-Méndez, A.; Báez-González, J.G.; Peralta-Reyes, E.; Trujillo-Tapia, M.N. Problem Based Learning: Obtaining Enzyme Kinetics Parameters Integrating Linear Algebra, Computer Programming and Biochemistry Curriculum. In Technological Developments in Networking, Education and Automation; Springer Science and Business Media LLC: Philadelphia, PA, USA, 2010. [CrossRef]

38. Sivarajasekar, N.; Mohanraj, N.; Sivamani, S.; Prakash Maran, J.; Moorthy, I.G.; Balasubramani, K. Statistical Optimization Studies on Adsorption of Ibuprofen onto Albizialebbeck Seed Pods Activated Carbon Prepared Using Microwave Irradiation. Mater. Today Proc. 2018, 5 Pt 2, 7264-7274. [CrossRef]

39. Hazime, R.; Nguyen, Q.H.; Ferronato, C.; Huynh, T.K.X.; Jaber, F.; Chovelon, J.-M. Optimization of Imazalil Removal in the System UV/TiO2/K2S2O8 Using a Response Surface Methodology (RSM). Appl. Catal. B Environ. 2013, 132-133, 519-526. [CrossRef]

40. Wu, F.-C. Optimization of Correlated Multiple Quality Characteristics Using Desirability Function. Qual. Eng. 2004, 17, 119-126. [CrossRef]

41. Amdoun, R.; Khelifi, L.; Khelifi-Slaoui, M.; Amroune, S.; Asch, M.; Assaf-Ducrocq, C.; Gontier, E. The Desirability Optimization Methodology; a Tool to Predict Two Antagonist Responses in Biotechnological Systems: Case of Biomass Growth and Hyoscyamine Content in Elicited Datura Starmonium Hairy Roots. Iran. J. Biotechnol. 2018, 16, e1339. [CrossRef]

42. Wang, C.; Yu, Y.; Yin, L.; Niu, J.; Hou, L.-A. Insights of Ibuprofen Electro-Oxidation on Metal-Oxide-Coated Ti Anodes: Kinetics, Energy Consumption and Reaction Mechanisms. Chemosphere 2016, 163, 584-591. [CrossRef] [PubMed]

43. Amado-Piña, D.; Roa-Morales, G.; Barrera-Díaz, C.; Balderas-Hernandez, P.; Romero, R.; Martín del Campo, E.; Natividad, R. Synergic Effect of Ozonation and Electrochemical Methods on Oxidation and Toxicity Reduction: Phenol Degradation. Fuel 2017, 198, 82-90. [CrossRef]

Publisher's Note: MDPI stays neutral with regard to jurisdictional claims in published maps and institutional affiliations.

(C) 2020 by the authors. Licensee MDPI, Basel, Switzerland. This article is an open access article distributed under the terms and conditions of the Creative Commons Attribution (CC BY) license (http://creativecommons.org/licenses/by/4.0/). 